\title{
PENGARUH MEDIA POP UP BOOK TERHADAP KETERAMPILAN MENULIS SISWA PADA MATA PELAJARAN BAHASA INDONESIA SD
}

\section{Isna Ilvi Nurrohmah, Suharmono Kasiyun, Nafi'ah, Muhammad Taufiq}

Surel: isnailvinurrohmah2@gmail.com

\begin{abstract}
The purpose of this research is to use of pop up book media for writing skills in Indonesian primary school subjects. The method used in this research is meta-analisys method. This research begins by formulating the topic to be examined, than make a statement of the problem, and than stage the collection of relevant articles to collect data. The data is obtained from online journal searches through Google Scholar. The keywords used are "Pop up book" and "elementary school writing skills". From search results there are 8 articles. The data obtained were analyzed again using quantitative method. Based on the results of Pop Up Book media analysis it can be proven to improve students' writing skills by an average before being given treatment is 57.58 and after being given treatment is 76.05 so that increases is 18.47 .
\end{abstract}

Keywords: Pop up Book Media, Skills Writing, Indonesian

\begin{abstract}
ABSTRAK
Sasaran dari penelitian ini adalah untuk mendeskripsikan pengaruh media Pop Up Book terhadap keterampilan menulis Mata Pelajaran Bahasa Indonesia SD. Penelitian ini menggunakan metode meta analisis. Penelitian ini diawali dengan merumuskan topik yang akan diteliti, kemudian membuat rumusan masalah, pada tahap selanjutnya pengumpulan artikel yang relevan untuk mengumpulkan data. Data tersebut diperoleh dari penelusuran jurnal online melalui google scholar. Kata kunci yang digunakan yakni "media Pop Up Book" dan "keterampilan menulis SD". Dari hasil penulusaran terdapat 8 artikel. Datayang diperoleh dianalisis kembali menggunakan metode kuantitatif. Berdasarkan hasil analisis media Pop Up Book dapat dibuktikan meningkatkan keterampilan menulis siswa dengan rata-rata sebelum diberikan perlakuan sebesar 57.58 dan sesudah deberikan perlakuan sebesar 76.05 sehingga meningkat 18.47 .
\end{abstract}

Kata Kunci: Media Pop Up Book, Keterampilan Menulis, Bahasa Indonesia

\section{PENDAHULUAN}

Bahasa dalam dunia pendidikan adalah alat komunikasi pertama dalam mengembangkan suatu pengetahuan. Bahasa merupakan pengantar atau landasan pada saat kegiatan pembelajaran. Dalam kehidupan sehari-hari pendidikan pembelajaran berbahasa dan sastra penting dipelajari. Terdapat empat aspek keterampilan dalam pembelajaran berbahasa dan sastra yang perlu diketahui yaitu menulis, membaca, berbicara dan mendengarkan (Yanti, Suhartono, dan Kurniawan, 2018: 74). Berkomunikasi, baik berkomunikasi secara langsung atau tidak langsung dilandasi oleh ke-empat aspek tersebut. Menyimak dan berbicara merupakan keterampilan secara langsung, sedangkan menulis dan membaca termasuk keterampilan 

tidak langsung. Keempat aspek tersebut mempunyai ketertarkaitan yang sangat erat meskipun mempunyai ciri-ciri tertentu, salah satunya yaitu keterampilan menulis (Darusuprapti, 2015: 14).

Menulis merupakan salah satu kegiatan yang dibutuhkan dari keterampilan bahasa lainnya, oleh sebab itu perlu diajarkan sejak dini, terutama di bangku sekolah dasar. Anak-anak memasuki masa sekolah dimulai dari bangku sekolah dasar. Menulis merupakan keterampilan seseorang yang didapatkan dengan cara tidak mudah, yaitu dengan cara berlatih yang diawali dengan berfikir, setelah itu apa yang difikirkan dituangkan atau ditulis disebuah kertas(Jannah dan Sukidi, 2018: 1812). Menurut Mulyati dan Supriyana (2010: 224) keterampilan berbahasa yang mempunyai sifat produktif dengan menghasilkan sebuah atau tulisan disebut keterampilan menulis.

\section{Pengajaran}

keterampilan

menulis sangatlah diperlukan akan tetapi penugasan tersebut kurang mendapat perhatian. Seperti

yang telah dikatakan oleh Susanto (2012: 251), bahwa dalam kehidupan sehari-hari keterampilan menulis adalah salah satu dari beberapa komponen terpenting yang dilakukan. Maka dalam pembelajaran menulis perlu adanya perhatian dari sekolah. Salah satu contoh aspek yang berkaitan dengan menulis yaitu mengarang. Bentuk karangan tersebut dapat berupa cerpen, deskripsi, narasi, puisi, dll. Aspek yang perlu diperhatikan dari kegiatan tersebut yaitu dapat membantu siswa dalam menambah perbendaharaan kosakata (Susanto, 2012: 247).

Dalam pembelajaran menulis, sering siswa kurang tertarik dalam menyelesaikan tugas tersebut. Penyebab kurangnya ketertarikan dalam menulis ada beberapa faktor, diantaranya siswa kurang faham dalam hal materi, siswa kurang tertarik dengan materi menulis karangan tersebut ataupun bosan dalam pemberian tugas yang harus diselesaikan. Oleh sebab itu dapat diperhatikan untuk memaksimalkan keterampilan menulis, misalnya dalam cerita pendek guru membutuhkan perencanaan strategi yang menarik agar dalam membuat karangan siswa lebih tertarik dan kreatif (Sukidi dan Jannah, 2018: 1812).

$\begin{array}{lrr}\text { Dalam } & \text { kagiatan } & \begin{array}{r}\text { belajar } \\ \text { pendidik }\end{array} \\ \text { mengajar } & \text { seorang } & \begin{array}{r}\text { pendik } \\ \text { mempersiapkan }\end{array}\end{array}$ perencanaan pembelajaran terlebih dahulu, agar materi yang disampaikan dapat dipahami dan memudahkan siswa tentunya. Untuk itu hendaknya guru perlu mengetahui metode pengajaran seperti yang digunakan dalam proses pembelajaran sehingga dapat mengkondisikan atau mengelola kelas dengan baik dan tepat. Sehingga membutuhkan strategi dalam mencapai tujuan pembelajaran. Dengan adanya strategi tersebut pembelajaran diharapkan dapat sesuai dengan tujuan dan dapat menarik perhatian siswa dalam kegiatan pembelajaran.

Media pembelajaran ialah salah satu strategi yang dapat memberikan daya tarik siswa dalam belajar. Dengan adanya media pembelajaran siswa akan timbul daya tarik dalam kegiatan pentransferan ilmu dan siswa akan lebih termotivasi, sehingga dalam menerima materi dari guru siswa akaan terbantu dengan penggunaan media pembelajaran. menerima materi dari guru. Menurut Djamarah dan Zain (2013: 121), 
media merupakan perangkat yang dapat membantu dalam menyajikan materi atau pesan untuk mencapai tujuan pembelajaran. Dengan adanya suatu media tersebut siswa akan aktif tidak hanya pada pendengaran saja namun juga aktif pada penglihatan dan sebagainya. Perlunya media pada saat mengajar yaitu siswa sebagai penerima informasi dapat memahami informasi atau pesan yang diberikan oleh guru. Penggunaan media juga melibatkan banyak indera, sehingga siswa lebih aktif dalam menerima materi.

Penggunaan media dalam pembelajaran menulis masih sedikit dan hasil yang didapatkan masih belum diperoleh secara maksimal. Salah satu cara menanggulangi permasalahan itu yaitu dengan menggunakann media pop up book. Sebuah buku yang mempunyai unsur tiga dimensi dan mempunyai komponen yang dapat bergerak disebut pop up book. Media pop up book memiliki ciri tersendiri yaitu ketika kita membuka dari lembar satu ke lembar selanjutnya gambar tersebut akan bergerak. (Montanaro, 2015: 124).

Menurut Nancy dan Rondha (2012: 1), pop up book adalah sebuah lembaran-lembaran yang memberikan gerakan melalui penggunaan kertas yang dibuat dengan cara melipat, digeser, ditekan dan diputar. Maksud dari kalimat tersebut adalah sebuah buku yang memberikan gerakangerakan dari penggunaan kertas yang dibentuk lipatan, gulungan, slide, tab, atau putaran.

Penggunaan media Pop up book bisa mendapatkan hasil yang lebih baik dalam meningkatkan keterampilan menulis siswa. Tidak hanya untuk meningkatkann siswa juga dapat mengurangi rasa bosan saat mengerjakan tugas karangan menulis. Dengan adanya pemilihan media yang tepat meudahkan dan lebih memotivasi siswa dalam menyelesaikan tugas keterampilan menulis.

\section{METODE PENELITIAN}

Penelitian ini menggunakan desain Meta-Analisis. Metode ini adalah penggunaan salah satu teknik untuk meringkas atau merangkum dua penelitian atau lebih yang bertujuan untuk menggabungkan, meninjau serta merangkum penelitian sebelumnya secara kuantitatif (Boisandi \& Handy Darmawan, 2017: 180). Meta-Analisis ini bersifat subjektif dibandingkan dengan metode yang lainya, yakni berfokus pada data. Google scholar sebagai perantara dalam pengumpulan data. Kata kunci yang digunakan dalam pencarian yaitu media Pop up book, dan keterampilan menulis.

Dari hasil penelusuran terdapat 8 artikel yang sudah diterbitkan di jurnal online dengan ketentuan berbentuk skor atau angka dari data sebelum dan sesudah penelitian.

\section{HASIL PENELITIAN DAN PEMBAHASAN}

Hasil penelitian yang diambil untuk penelitian meta-analisis ini yaitu:

- Penggunaan Media "Pop $U p$ Book" Untuk Meningkatkan Keterampilan Menulis Deskripsi Siswa Kelas IV SDN Cerme LorGresik oleh Setyowati, Dwi Kurnia. Maryam Isnaini.

- Pengaruh Penggunaan Media Pop Up Book Terhadap Keterampilan Menulis Narasi Siswa Sekolah Dasar oleh Sylvia, Nur Indah. Sri Hariani. 
- Pengaruh Penggunaan Media Pop Up Book Terhadap Keterampilan Menulis Deskriptif Siswa Kelas IV SDN Babatan I Surabaya oleh Jannha, Siti Nur. Masengut Sukidi.

- Peningkatan Keterampilan Menulis Dongeng Melalui Media Pop Up Book Pada Siswa Kelas IV A SDN Jegeran Sewon oleh Kamaludin, Haryati.

- Peningkatan Keterampilan Menulis Cerpen Menggunakan Media Pop Up Book Untuk Siswa Kelas IV SD Muhammadiyah Sidokerto Godean Sleman Yogyakarta oleh Darusuprapti, Fajarasih.
- Peningkatan Keterampilan Menulis Deskripsi Melalui Media Pop Up Book Pada Siswa Kelas II SDN Brengosan I oleh Rizki, Annisa Amalia.

- Peningkatan Keterampilan Menulis Narasi Melalui Media Pop Up Bookoleh Rahmawati, Eni. Siti Istiyati. Siti Kamsiati dan Imam Sriyanto.

- Penggunaan Media Pop Up Book Sebagai Peningkata Keterampilan Menulis Karangan Narasi Ekspositori oleh Saputra, Anggi. Ahmad Mulyadiprana. Dia Indihadi.

Tabel 1. Hasil Analisis Pembelajaran Menggunakan Media Pop Up Book

\begin{tabular}{|c|c|c|c|c|c|}
\hline \multirow{2}{*}{ No } & \multirow{2}{*}{$\begin{array}{c}\text { Topik } \\
\text { Penelitian }\end{array}$} & \multirow{2}{*}{ Peneliti } & \multicolumn{3}{|c|}{ Peningkatan Hasil Belajar } \\
\hline & & & Sebelum & Sesudah & Gain \\
\hline 1 & $\begin{array}{l}\text { Media Pop } \\
\text { Up Book, } \\
\text { Keterampilan } \\
\text { menulis } \\
\text { Deskripsi }\end{array}$ & $\begin{array}{l}\text { Dwi Kurnia } \\
\text { Setyowati, } \\
\text { Maryam } \\
\text { Isnaini. }\end{array}$ & 69 & 91 & 22 \\
\hline 2 & $\begin{array}{l}\text { Media Pop } \\
\text { Up Book, } \\
\text { Keterampilan } \\
\text { Menulis } \\
\text { Narasi } \\
\end{array}$ & $\begin{array}{lr}\text { Nur } & \text { Indah } \\
\text { Sylvia, } & \text { Sri } \\
\text { Hariani. } & \\
\end{array}$ & 52.76 & 74.12 & 21.36 \\
\hline 3 & $\begin{array}{l}\text { Media Pop } \\
\text { Up Book, } \\
\text { Keterampilan } \\
\text { Menulis } \\
\text { Deskriptif }\end{array}$ & $\begin{array}{l}\text { Siti Nur } \\
\text { Jannah, } \\
\text { Masengut } \\
\text { Sukidi. }\end{array}$ & 72.13 & 91.97 & 19.84 \\
\hline 4 & $\begin{array}{l}\text { Keterampilan } \\
\text { menulis } \\
\text { dongeng, } \\
\text { Media Pop } \\
\text { up book }\end{array}$ & $\begin{array}{l}\text { Haryati } \\
\text { Kamaludin }\end{array}$ & 66.8 & 91.63 & 24.83 \\
\hline 5 & $\begin{array}{l}\text { Keterampilan } \\
\text { menulis } \\
\text { cerpen, } \\
\text { Media Pop } \\
\text { up book }\end{array}$ & $\begin{array}{l}\text { Fajarasih } \\
\text { Darusuprapti } \\
\text { dan Haryanto }\end{array}$ & 59.9 & 85.75 & 25.85 \\
\hline
\end{tabular}


Isna Ilvi Nurrohmah : Pengaruh Media Pop Up ...

\begin{tabular}{|c|c|c|c|c|c|}
\hline \multirow{2}{*}{ No } & \multirow{2}{*}{$\begin{array}{c}\text { Topik } \\
\text { Penelitian }\end{array}$} & \multirow{2}{*}{ Peneliti } & \multicolumn{3}{|c|}{ Peningkatan Hasil Belajar } \\
\hline & & & Sebelum & Sesudah & Gain \\
\hline 6 & $\begin{array}{l}\text { Keterampilan } \\
\text { menulis } \\
\text { deskripsi, } \\
\text { Media Pop } \\
\text { up book }\end{array}$ & $\begin{array}{l}\text { Annisa } \\
\text { Amelia Rizki }\end{array}$ & 67.38 & 81 & 13.62 \\
\hline 7 & $\begin{array}{l}\text { Keterampilan } \\
\text { menulis } \\
\text { narasi, Media } \\
\text { Pop up book }\end{array}$ & $\begin{array}{l}\text { Eni } \\
\text { rahmawati, } \\
\text { SIti Istiyati, } \\
\text { Siti Kamsiati, } \\
\text { Imam } \\
\text { Sriyanto }\end{array}$ & 63.79 & 82 & 18.21 \\
\hline 8 & $\begin{array}{l}\text { Media Pop } \\
\text { up book, } \\
\text { Keterampilan } \\
\text { menulis } \\
\text { karangan } \\
\text { narasi } \\
\text { Ekspositori }\end{array}$ & $\begin{array}{l}\text { Anggi } \\
\text { saputra, } \\
\text { Ahmad } \\
\text { Mulyadiprana } \\
\text { Indrihadi Dia }\end{array}$ & 8.9 & 10.96 & 2.06 \\
\hline \multicolumn{3}{|c|}{$\begin{array}{l}\text { Pembelajaran menggunakan Pop up book atau } \\
\text { pemetaan pikiran (mean) }\end{array}$} & 57.58 & 76.05 & 18.47 \\
\hline
\end{tabular}

Pada tahap ini mulai menggabungkan ke 8 artikel yang akan dijadikan dasar dalam penelitian ini. Data pada tabel 1 terdiri dari rata-rata sebelum dan sesudah penggunaan media Pop up book dan gain pada setiap data penelitian.

Tabel 2. Paired Sample Statistics

\begin{tabular}{l|l|c|c|c|c}
\hline \multicolumn{7}{c}{ Paired Sample Statistics } \\
\hline \multicolumn{2}{|c|}{} & Mean & $\mathrm{N}$ & $\begin{array}{c}\text { Std. } \\
\text { Deviation }\end{array}$ & $\begin{array}{c}\text { Std. Error } \\
\text { Mean }\end{array}$ \\
\hline \multirow{2}{*}{ Pair 1 } & Sebelum & 57.58 & 8 & 20.56380 & 7.27040 \\
\cline { 2 - 6 } & Sesudah & 76.05 & 8 & 27.02938 & 9.55633 \\
\hline
\end{tabular}

Berdasarkan pada tabel 2. tindakan atau menggunakan media Paired Sample Statistics Pop Up Book dapat meningkat. Ratamemperlihatkan bahwa rata-rata rata keterampilan menulis siswa naik keterampilan menulis siswa antara dari 57.58 menjadi 76.05. sebelum dan sesudah menggunakan

Tabel 3.Paired Samples Correlations

\begin{tabular}{ll|c|c|c}
\hline \multicolumn{5}{c}{ Paired Sample Correlation } \\
\hline & $\mathrm{N}$ & Correlation & Sig. \\
\hline Pair 1 & Sebelum \& Sesudah & 8 & .985 & .000 \\
\hline
\end{tabular}


Berdasarkan tabel 3. Paired Sample Correlations menunjukkan bahwa sebelum dan setelah penggunaan media terdapat korelasi nilai rata-rata keterampilan menulis siswa dalam penggunaan media pop upbook.

Tabel 4. Paired Sample Test

\begin{tabular}{|c|c|c|c|c|c|c|c|c|c|}
\hline & & \multicolumn{5}{|c|}{ Paired Differences } & \multirow[b]{3}{*}{$\mathbf{t}$} & \multirow[b]{3}{*}{ df } & \multirow{3}{*}{$\begin{array}{l}\text { Sig. }(2 \\
\text { tailed }\end{array}$} \\
\hline & & \multirow[b]{2}{*}{ Mean } & \multirow{2}{*}{$\begin{array}{c}\text { Std. } \\
\text { Deviation } \\
\end{array}$} & \multirow{2}{*}{$\begin{array}{c}\text { Std. Error } \\
\text { Mean }\end{array}$} & \multicolumn{2}{|c|}{$\begin{array}{l}\text { 95\% Convidence } \\
\text { Interval of the } \\
\text { Difference }\end{array}$} & & & \\
\hline & & & & & Lower & Upper & & & \\
\hline $\begin{array}{c}\text { Pair } \\
1\end{array}$ & $\begin{array}{l}\text { Sebelum } \\
\text {-Sesudah }\end{array}$ & -1.84711 & 7.65770 & 2.70740 & $\begin{array}{c}- \\
24.873 \\
24\end{array}$ & -12.06926 & -6.822 & 7 & .000 \\
\hline
\end{tabular}

Berdasarkan tabel 4. Paired Sample Test menunjukkan bahwa $\mathrm{H}_{0}$ = tidak adanya pengaruh yang signifikan terhadap keterampilan menulis siswa antara sebelum dan sesudah diberikannya perlakuan dan $\mathrm{H}_{1}=$ adanya pengaruh yang signifikan terhdap keterampilan menulis siswa antara sebelum dan setelah diberikannya perlakuan. Dari tabel 4 dapat dikatakan apabila $\mathrm{H}_{0}$ diterima jika nilai Sig. (2-tailed) > 0.05 dan menolak $\mathrm{H}_{0}$ atau menerima $\mathrm{H}_{1}$ jika nilai Sig. (2-tiled) $<0.05$. Jadi dapat disimpulkan bahwa adanya pengaruh yang signifikan terhadap keterampilan menulis siswa setelah diberikannya perlakuan atau media pembelajaran tersebut.

\section{Pembahasan}

Berdasarkan hasil penelitian, secara umum mendapat beberapa data bahwa dengan pengaruh penggunaan Pop Up Book terhadap keterampilan menulis siswa SD dapat memberikan dampak positif. Dilihat dari tabel 1 menunjukkan bahwa masing-masing penelitian yang telah diteliti sebelumnya memperoleh peningkatan rata-rata keterampila menulis sesudah menggunakan media Pop Up Book dengan gain paling rendah yaitu 2.06 sedangkan yag paling tinggi yaitu
25.85 dan rata-rata akhir gain sebesar 18.47 .

Sedangkan jika dilihat dari rata-rata hasil keterampilan menulis sebelum dan setelah digunakannya media Pop Up Book pada tabel 2 menunjukkan bahwa hasil keterampilan menulis siswa antara sebelum dan setelah menggunaka media Pop Up Book terjadi peningkatan. Sebelum menggunakan media Pop Up Book rata-rata hasil keterampilan menulis siswa dari 8 artikel tersebut sebesar 57.58, sementara mean dari hasil keterampilan menulis siswa sebesar 76.05 sesudah diberikannya perlakuan.

Pada tabel 3 menunjukkan bahwa adanya correlation antara keterampilan menulis siswa dan media Pop Up Book. Hasil dari korelasi tersebut sebesar 0.985 dengan sig. sebesar 0.000. Hal ini memperlihatkan antara sebelum dan sesudah adanya perlakuan terdapat hubungan/korelasi yang kuat atau signifikan dalam penerapan media Pop Up Book.

Berdasarkan hasil analisis di atas dapa disimpulkan bahwa pembelajaran menggunakan media Pop Up Book dapat meningkatkan keterampilan menulis siswa SD. Pada tabel 1, terdapat 8 sampel penelitian 
yang telah diteliti sebelumnya yang memiliki hasil akhir peningkatan yang berbeda-beda, meskipun tiap penelitian menunjukkan peningkatan antara sebelum dan sesudah penggunaan media Pop Up Book.Hal tersebut dikarenakan kondisi antara satu siswa dengan siswa yang lain tidak sama.

Disamping itu saat pembelajaran ada beberapa faktor yang dapat mempengaruhi kondisi siswa. Misalnya faktor dari dalam, siswa mengikuti pembelajaran dalam kodisi yang kurang baik atau kondisi kesehatan yang tidak baik. Adapun faktor dari luar juga berpengaruh terhadap kondisi siswa, misalnya ligkungan sekolah, kondisi sekolah atau letak sekolah yang dekat dengan jalan raya. Beberapa hal tersebut bisa menimbulkan kurangnya konsentrasi dan minat belajar siswa dalam mengikuti pembelajaran.

\section{SIMPULAN}

Hasil akhir dari analisis dan pembahasan dapat disimpulkan bahwa media Pop up book dapat menjawab permasalahan yang telah dirumuskan pada rumusan masalah. Penggunaan media Pop Up Book dapat memberika pengaruh terhadap keterampilan menulis siswa pada mata pelajaran Bahasa Indonesia SD. Hal ini dapat ditinjau dari data setelah diperlakukannya penggunaan media Pop Up Book.Hasil keterampila meulis siswa tergolong tinggi dari 8 sampel penelitian terdapat hasil ratarata 76.05 dari sebelumnya 57.58. Dari data tersebut terjadi kenaikan yang signifikan yaitu sebesar 18.47 yang artinya penggunaan media $P o p$ Up Book terhadap keterampilan menulis siswa SD mempunyai pengaruh yang positif.

\section{DAFTAR RUJUKAN}

Boisandi dan Handy Darmawan. 2017. Meta Analisis Pengaruh Penempatan Pembelajaran Berbasis Kontruktivisme Pada Materi Fisika Di Kalimantan Barat. Fakultas Pendidikan MIPA dan teknologi, IKIP-PGRI Pontianak. Jurnal Ilmiah Pendidikan Fisika Al-BiRuNi 06 (2) (2017) 179-185.

Darusuprapti, Fajarasih dan Haryanto. 2019. Peningkatan Keterampilan Menulis Cerita Pendek Menggunakan Media Pembelajaran Pop Up. Program Pascasarjana, FIP, Universitas Negeri Yogyakarta. Widyaparwa, Volume 47, Nomor 1, Juni 2019.

Darusuprapti, Fajarasih. 2015. Peningkatan Keterampilan Menulis cerita Pendek Menggunakan Media Pop Up Book untuk Siswa Kelas IV SD Muhammadiyah Sidokarto Godean Sleman Yogyakarta. Skripsi Tidak diterbitkan. Yogyakarta: Universitas Negeri Yogyakarta.

Djamarah, S. B., \& Zain, A. 2013. Strategi Belajar Mengajar. Jakarta: Rineka Cipta.

Janah, Siti Nur, Maseegut Sukidi. 2018. Pengaruh Penggunaan Media Pop Up Book Terhadap Keterampilan Menulis Deskripsi Siswa Kelas IV SDN Babatan 1 Surabaya. Jurnal PGSD. Volume O6 Nomor 10. UNESA.

Kamaludin, Haryati. 2017. Peningkatan Keterampilan Menulis Dongeng Melalui Media Pop Up Book Pada Siswa Kelas IV SDN Jageran Sewon. PGSD FIP, Universitas Negeri Yogyakarta. Jurnal Pendidikan Guru Sekolah Dasar Edisi 6 Tahun ke-6 2017. 
Mulyati, Yeti \& Asep Supriyana. 2010. Bahasa Indonesia. Jakarta: Universitas Terbuka.

Nancy dan Rondha. 2012. Pop Up Books: A Guide for Teacher and Librarians. California: Santa Barbara.

Rahmawati, Eni., Siti Istiyati, Siti Kamsiyati dan M. Ismail Sriyanto. 2016. Peningkatan Keterampilan Menulis Narasi Melalui Media Pop Up Book. FKIP, Universitas Sebelas Maret Surakarta. Jurnal Pendidikan Universitas Sebelas Maret Surakarta.

Rizki, Annisa Amalia. 2018. Peningkatan Keterampilan Menuliis Deskripsi Melalui Media Pop Up Book Pada Siswa Kelas II SDN Brengosan 1. Universitas Negeri Yogyakarta. Jurnal Pendidikan Guru Sekolah Dasar Edisi 34 Tahun ke-7 2018.

Saputra, Anggi., Ahmad Mulyadiprana dan Dian Indihadi. 2017. Penggunaan Media Pop Up Sebagai Peningkatan Keterampilan Menulis Karangan Narasi Ekspositori. PGSD, Universitas pendidikan Indonesia Kampus Tasikmalaya. PEDADIDAKTKA: Jurnal Ilmiah Pendidikan Guru Sekolah Dasar. Vol. 4, No. 2 (2017) 76-84.

Setyowati, Dwi Kurnia dan Maryam Isnaini Damayanti. 2017. Penggunaan Media Pop Up Book Untuk Meningkatkan Keterampilan Menulis Deskripsi Siswa Kelas IV SDN Crème Lor Gresik. PGSD FIP, Universitas Negeri Surabaya. Jurnal ilmiah JPGSD. Volume 05 Nomor 03 Tahun 2017.
Susanto, Ahmad. 2013. Teori Belajar dan Pembelajaran. Jakarta: Prenadamedia Group.

Sylvia, Nur Indah dan Sri Harianni. 2015. Pengaruh Penggunaan Media Pop Up Book Terhadap Keterampilan Menulis Narasi Siswa Sekolah Dasar. PGSD FIP, Universitas Negeri Surabaya. JPGSD, Volume 03 Nomor 02 Tahun 2015.

Yanti, Nafri., Suhartono dan Rio Kurniawan. 2018. Penguasaan Materi Pembelajaran Keterampilan Berbahasa Indonesia Pendidika Bahasa dan Sastra Indonesia FKIP Universitas Bengkulu. FKIP, Universitas Bengkulu. Jurnal Ilmiah Korpus, Volume II, Nomor 1, April 2018. 